\title{
RELATIONSHIPS BEETWEEN COPING STRATEGIES AND PSYCHOACTIVE SUBSTANCE USE
}

\author{
Danica Keczeli \\ Clinical- and sport psychologist \\ University of Debrecen, Faculty of Economic Sciences, \\ Department of Sport Economics and Management, Debrecen \\ keczeli.danica@cts.hu
}

\begin{abstract}
The study examines the relationship between coping strategies and smoking and alcohol consumption among athletes, recreational athletes and non-athlete individuals.

The factors examined were measured by a validated questionnaire version of Folkman-Lazarus (1980) (Ways of coping) (16 items) and asked about the smoking and alcohol consumption patterns of the respondents. The total sample number was 813 people, of whom 341 were athletes, 292 were recreational and 180 were non-athletes. $54.4 \%$ of the sample is female and $45.6 \%$ is male. In my research, I focused on mapping intrapersonal coping strategies among athletes, recreational athletes, and the non-athlete individuals, and explored gender differences. Furthermore, how smoking and alcohol consumption appear as a negative coping strategy in the measured sample.

As a method besides descriptive statistics the Kolmogorov-Smirnov test was used to verify normality, and the hypotheses were tested with nonparameterized test (Kruskal-Wallis, and Mann-Whitney).

For coping strategies I found a significant difference among the non-, recreational and competitive athletes, and there is a significant difference between genders as well.

In the case of cognitive restructurings, there was a significant difference in favor of sports and recreational athletes versus non-athletes, while in problem analysis and passive coping I found a significant difference in favor of women compared to men.

Significant differences were also found in the case of psychoactive substance use. Among the three groups, as the intensity of sport increases, the number of smokers decreases. In the case of smoking, a significant difference was found in the coping strategies referring to reduction of the stress in the whole sample. In the case of alcohol consumption, in coping strategies were found significant differences between stress reduction, problem analysis and passive coping.
\end{abstract}

Keywords: coping strategies, leisure sports, competitive sports, non-athletes

\section{INTRODUCTION}

Appropriate management of frustration- and conflict-laden situations greatly influences our interpersonal relationships and has a great effect on our professional efficiency as well as psychological and health condition (McMURRAN AND McGUIRE, 2005). In today's world so full of stress (especially in competitive sport, where stress, performance centricity and the danger of injury are always present) it is necessary to familiarise ourselves with the intrapersonal coping modes that people can use to react to both external and internal impacts. Studying and learning coping strategies can promote the development of the selection process and can also serve as a yardstick during the sportspeople's training process to ensure the most effective work possible since, in addition to secure efficiency, one of the many aims of competitive sport is to prepare healthy people for civilian life.

With regard to coping strategies, we distinguish between positive and negative ways of coping, much like in the case of stress. During positive coping mechanisms, no side effects occur while during use of negative ways of coping there are some kind of harmful effects. According to this, positive ways of coping are sport, relaxation, humour, laughter or crying, whereas some examples of negative ways of coping 
are alcohol consumption, drug use or (over)eating (KOPP, 1995). Negative coping strategies can be useful during the coping process while they carry some kind of risk, too, as, for example, smoking can cause health problems.

Sport is a positive coping strategy since an appropriate degree of sporting activity is capable of reducing tension, can restore the body's balance and has no harmful side effects. Sport plays an important role in the prevention of the formation of harmful habits (PIKÓ, 2000; MIKULÁN ET AL., 2010). However, there is some research that questions the role of sport, and, within it, competitive sport, as a protective factor against alcohol consumption and smoking (VINGENDER, 2003).

The coping mechanisms that we use influence our decisions regarding behaviour, including our health behaviours (PLUHÁR AND PIKÓ, 2003). In this study I placed particular emphasis on mapping and assessing coping mechanisms among competitive and leisure time sportspeople as well as non-athlete individuals. I also examined how alcohol consumption and smoking appear on the examined sample as negative coping strategies. Furthermore, I examined the differences between male and female individuals.

\section{LITERATURE}

Coping strategies are cognitive, psychological and behavioural patterns used by people to overcome, reduce, or tolerate the hardships of a stressful life situation. This effort does not necessarily appear as some kind of action; instead, it can represent a certain notional-emotional relation. Cognitive recognition of the noxious nature of the situation is a necessary condition for the appearance of coping behaviour.

Any situation in which interaction between an individual and their environment requires a novel response is regarded as a stress situation (KOPP, 2003). How the individual sees these situations (joyous, pleasant or unpleasant, upsetting) depends on the individual's evaluation. In difficult, and upsetting situations an emotional, notional, and physiological condition develops, which urges the individual to terminate or reduce this situation (MARGITICS AND PAUWLIK, 2006).

According to the psychoanalytical approach (Freud, 1986) coping means "those manoeuvres of the ego that it uses to manage threats from the external world" (OLÁH, 2005, p. 53). In the personality trait theories, coping appears as a stable, lasting characteristic of the personality, suggesting that the given reactions to stress depend on the environment to a small degree only (BYRNE, 1964). In his research KROHNE (1993) draws attention to the fact that personality traits most often regulate coping as a response to the environment. Much later OLÁH (2005) concluded that coping mechanisms are components of personality traits, habits used by the individual in stress situations. According to Lazarus's transactional theory of stress and coping (1966) coping is a kind of behaviour regulator which moderates interactions between the individual and their environment in an inadequate (upsetting, disturbing) situation. In this process cognitive evaluation plays an important role, i.e., response does not derive from emotions, instead, emotion itself is a result of cognitive evaluation as are coping strategies (OLÁH, 2005).

According to the stress, appraisal and emotion transactional model (LAZARUS \& FOLKMAN, 1984), the most widely used model in sport, coping strategies are ways of managing problems or situations. NICHOLLS \& POLMAN (2007a) suggest that an individual should continuously evaluate transactions in connections with their environment. NICHOLLS ET AL. (2007) found that diverse coping strategies such as crying or even alcohol and drug use are used in sport (KOWALSKI AND CROCKER, 2001).

There are several different classifications in the literature to describe coping strategies (FOLKMAN AND LAZARUS, 1980; ALDWIN AND REVENSON, 1987; SCHWARZER AND SCHWARZER, 1996). The problem-focussed type comprises activities targeting analysis and then solution while the emotion-focussed type covers efforts to ease the tension generated in the stress situation, minimise or avert the problem (FOLKMAN AND LAZARUS, 1980; LÁZÁR AND FOLKMAN, 1984; KOPP AND SKRABSKI, 1992; RÓZSA ET AL., 2008). Coping focusing on emotions focuses on managing emotions. Within these categories a lot of coping strategies are used (WETHINGTON AND KESSLER, 1991). Some of these can be, among other things, avoiding problems, and alcohol or drug use (CARVER ET AL., 1989). Some sportspeople turn to religion for support or seek assistance from other people.

The appraisal process has two forms: primary and secondary appraisal. Primary appraisal occurs when individuals encounter noxious life events, in other words, potential stressors and decide whether the particular event has a positive or negative meaning to them. In the case of a negative meaning it is followed by reflection or re-thinking of the event followed by the decision about whether the given negative event (1) represents a momentary danger or (2) a lasting threat, which potentially threatens the future, too, or (3) should be considered a challenge. Primary appraisal is usually not a conscious process.

In the process of secondary appraisal an individual takes stock of their resources, the controllability of the situation and the potential responses and ways of coping that they can use to manage the situation. Inadequacy of the psychological coping resources leads to stress.

The key to health can be efficient coping with stress, the efficient functioning of the personality components and the interrelation of the dimensions of health and illness.

Examination of the use of coping strategies can be very useful among sports people since they are exposed to diverse loads. On one side there are the coach's expectations, which can concern the sportsperson's performance or their behaviour within or outside their group, and all this can represent great pressure. As a person competes at a higher level, the number and nature of expectations can increase. Too much load can lead to a disturbance in the functioning of the person's nervous system, potentially making decision-making difficult, too, and can eventually result in a deterioration of the person's performance (FREDERICK AND RYAN, 1993, as cited in 
KYPRIANOU ET AL., 2009). All this can have an effect on the individual's mental condition, too, even potentially causing anxiety, depression, eating disorder or other mental disorders.

In this study I examined diverse coping strategies among young adults. I wanted to find an answer to the question what kind of coping strategies occur among individuals doing competitive and leisure-time sport on the one hand, and nonathlete individuals on the other. My premise was that use of coping strategies can be greatly affected by doing sport and the intensity of that sport. I also assumed differences between male and female sportspeople.

In my study I also investigated the question how smoking and alcohol use as negative ways of coping effect intrapersonal ways of coping.

\section{MATERIALS AND METHODS}

The basis for my study was my own on-line survey. Sample size was 813 people $(\mathrm{N}=813)$, of whom $442(45.6 \%)$ were females and $371(54.4 \%)$ males. Based on aggregate data, $41.94 \%$ of the sample regarded themselves as individuals doing competitive sports, $35.91 \%$ leisure-time sportspeople, 22.14 referred to themselves as non-athlete individuals.

$17.2 \%$ of the respondents were under 18 years of age, $22.0 \%$ were between 18 and, $29.9 \%$ between 21 and 23, $16.7 \%$ between 24 and 29 , and $14.1 \%$ were 30 and over. $48.2 \%$ of the respondents were students, $43.6 \%$ were in full-time employment with $8.2 \%$ employed part time or receiving some kind of provision. $25.5 \%$ of the sample had basic level, $52.0 \%$ intermediate level, and $22.5 \%$ had higher level qualifications.

$78.1 \%$ of the respondents judged their income to be average, $4.2 \%$-a thought it was below average, and $17.5 \%$ deemed their financial situation above average.

Taking the questionnaire took place on the Internet and by personally contacting various schools and sports organisations and sports clubs. Completion of the complete questionnaire took about 12-14 minutes. The full questionnaire comprises sociodemographic variables on the one hand, and eight standardised and reliable measuring tools on the other. In this study I wanted to find an answer to the question whether, in terms of coping strategies, the beneficial effect of sport appears in individuals pursuing competitive and leisuretime sports compared with non-athete individuals. I also investigated whether smoking and alcohol use are present as negative coping strategies among respondents, and if so, in what form.

To study conflict-solving strategies I used the shortened, FOLKMAN-LAZARUS (1980) (Ways of coping) (KOPP AND SKRABSKI, 1992; RÓZSA ET AL., 2008) questionnaire also used in epidemiological surveys (Hungarostudy 1988, 1995, 2002). It measures the applicability of the Conflict-Solving Questionnaire to various difficult life situations and the stability of coping strategies. Factor analysis of the 16 items of the Conflict-Solving Questionnaire revealed the following four dimensions: Cognitive Restructuring, Tension Reduction, Problem Analysis, and Passive Coping.

In connection with a life situation that the respondents deemed especially difficult they used a four-point scale to show whether the ways of coping described in the list were typical of their behaviours in the weeks that followed the event and if so, to what extent.

I also assessed the smoking and alcohol use habits of the sample.

Statistical analysis of the data was done using SPSS 25.0 statistical software. In addition to descriptive statistics, I also used the Kolmogorov-Smirnov test to check normality and checked my hypotheses using nonparametric tests (KruskalWallis, and Mann-Whitney). I considered the results of the statistical tests significant at $\mathrm{p}<0,05$.

\section{RESULTS}

This study focuses on how conflict-solving strategies work among competitive and leisure-time sportspeople as well as non-athlete individuals.

In terms of the entire sample, Table 1 shows minimum and maximum values of the four factors of conflict-solving strategies as well as means per factor and distribution.

Table 1: Mean values of coping strategies in the entire sample

\begin{tabular}{|l|c|c|c|c|c|}
\hline & $\mathrm{N}$ & Min. & Max. & Mean & St.dev. \\
\hline $\begin{array}{l}\text { Cognitive } \\
\text { restructuring }\end{array}$ & 813 & 0,00 & 5,00 & 2,61 & 0,50 \\
\hline $\begin{array}{l}\text { Tension reduc- } \\
\text { tion }\end{array}$ & 813 & 0,00 & 4,00 & 1,80 & 0,63 \\
\hline $\begin{array}{l}\text { Problem- } \\
\text { analysis }\end{array}$ & 813 & 0,00 & 4,00 & 2,81 & 0,46 \\
\hline Passive coping & 813 & 0,00 & 4,00 & 1,62 & 0,65 \\
\hline
\end{tabular}

Source: own resource

Pearson's correlation table (Table 2) represents the strength of the relationship among the variables. Cognitive restructuring shows a mild correlation with tension reduction, medium with problem analysis and a weak correlation with passive coping.

Tension reduction shows a weak correlation with problem analysis and a medium one with passive coping. The correlation is also weak between problem-analysis and passive coping.

Table 2: Pearson's correlation values of coping strategies

\begin{tabular}{|c|c|c|c|c|}
\hline $\begin{array}{l}\text { Pearson's } \\
\text { correlation }\end{array}$ & $\begin{array}{l}\text { Cognitive } \\
\text { restructuring }\end{array}$ & $\begin{array}{l}\text { Tension } \\
\text { reduction }\end{array}$ & $\begin{array}{l}\text { Problem } \\
\text { analysis }\end{array}$ & $\begin{array}{l}\text { Passive } \\
\text { coping }\end{array}$ \\
\hline $\begin{array}{l}\text { Cognitive } \\
\text { restructuring }\end{array}$ & 1 & $0,077 *$ & $0,380 * *$ & $0,160 * *$ \\
\hline $\begin{array}{l}\text { Tension } \\
\text { reduction }\end{array}$ & & 1 & $0,175^{* *}$ & $0,334 * *$ \\
\hline $\begin{array}{l}\text { Problem } \\
\text { analysis }\end{array}$ & & & 1 & $0,118 * *$ \\
\hline $\begin{array}{l}\text { Passive } \\
\text { coping }\end{array}$ & & & & 1 \\
\hline
\end{tabular}

Source: own resource 
My first hypothesis was that there was a difference between the three examined groups in terms of coping strategies.

None of the examined variables having showed normal distribution ((Kolmogorov-Smirnov, $\mathrm{p}<0.05$ in each case), I tested this hypothesis using the Kruskal-Wallis $\mathrm{H}$ test. The three examined groups showed a significant difference in the cognitive restructuring coping mode $(\mathrm{p}=0.007)$ (Table 3$)$.

Table 3: Differences between competitive and leisure-time sportspeople and non-athletes

\begin{tabular}{|l|l|l|l|l|}
\hline & $\begin{array}{l}\text { Cognitive } \\
\text { restructur- } \\
\text { ing }\end{array}$ & $\begin{array}{l}\text { Tension } \\
\text { reduction }\end{array}$ & $\begin{array}{l}\text { Problem } \\
\text { analysis }\end{array}$ & $\begin{array}{l}\text { Passive } \\
\text { coping }\end{array}$ \\
\hline $\begin{array}{l}\text { Kruskal- } \\
\text { Wallis H }\end{array}$ & 9,91 & 3,58 & 1,32 & 2,02 \\
\hline df & 2 & 2 & 2 & 2 \\
\hline $\begin{array}{l}\text { Signifikan- } \\
\text { cia }\end{array}$ & 0,007 & 0,167 & 0,517 & 0,365 \\
\hline
\end{tabular}

Source: own resource

The differences are also supported by Table 4, which shows the mean values and distributions of the coping strategies among competitive and leisure-time sportspeople and non-athlete individuals. As can be seen in the table, the mean values of the competitive and leisure-time sports people differ significantly in terms of the cognitive restructuring coping mode from those of non-athlete individuals. Furthermore, in terms of tension-reduction and problem analysis there was a mild difference in favour of the sportspeople while in terms of passive coping non-athletes showed higher values (Table 4.).

Table 4: Mean value and deviation of coping strategies among competitive, leisure athlete and non-athletes

\begin{tabular}{|l|l|l|l|l|l|l|}
\hline & \multicolumn{2}{|c|}{$\begin{array}{r}\text { Competitive } \\
\text { sportspeople } \\
(\mathrm{N}=341)\end{array}$} & \multicolumn{2}{c|}{$\begin{array}{r}\text { Leisure-time } \\
\text { sportspeople } \\
(\mathrm{N}=292)\end{array}$} & \multicolumn{2}{c|}{$\begin{array}{l}\text { Non-athlete indi- } \\
\text { viduals (N=180) }\end{array}$} \\
\hline & Mean & St.dev. & Mean & St.dev. & Mean & St.dev. \\
\hline $\begin{array}{l}\text { Cognitive } \\
\text { restructur- } \\
\text { ing }\end{array}$ & 2,64 & 0,47 & 2,64 & 0,49 & 2,48 & 0,54 \\
\hline $\begin{array}{l}\text { Tension } \\
\text { reduction }\end{array}$ & 1,77 & 0,62 & 1,79 & 0,62 & 1,89 & 0,67 \\
\hline $\begin{array}{l}\text { Problem } \\
\text { analysis }\end{array}$ & 2,82 & 0,46 & 2,83 & 0,40 & 2,76 & 0,53 \\
\hline $\begin{array}{l}\text { Passive } \\
\text { coping }\end{array}$ & 1,59 & 0,65 & 1,64 & 0,62 & 1,65 & 0,72 \\
\hline
\end{tabular}

Source: Own resource

My second hypothesis assumed that there was a difference between the genders in terms of coping strategies. I analysed my hypothesis using the MannWhitney Test and was able to show that female members of the sample had a significantly higher rate of passive coping $(p=0.017)$ than male members. I also found a significant difference $(\mathrm{p}<0.001)$ in terms of problem-analysis as well (Table 5).

Table 5: Difference(s) between females and males in terms of coping strategies

\begin{tabular}{|l|l|l|l|l|}
\hline & $\begin{array}{l}\text { Cognitive } \\
\text { restructuring }\end{array}$ & $\begin{array}{l}\text { Tension } \\
\text { reduction }\end{array}$ & $\begin{array}{l}\text { Problem } \\
\text { analysis }\end{array}$ & $\begin{array}{l}\text { Passive } \\
\text { coping }\end{array}$ \\
\hline Mann-Whitney & 77637,50 & 81279,00 & 68520,50 & 74347,50 \\
\hline Wilcoxon W & 175540,50 & 150285,00 & 137526,50 & 143353,50 \\
\hline Z & $-1,31$ & $-0,22$ & $-4,10$ & $-2,40$ \\
\hline Signifikancia & 0,190 & 0,828 & $<0,001$ & 0,017 \\
\hline
\end{tabular}

\section{Source: Own resource}

The differences between the genders are shown in Table 6 , too. It was males that showed higher mean values in terms of cognitive restructuring and tension reduction while females showed high mean values in terms of problem analysis and passive coping.

Table 6: Mean values across genders and distributions in terms of coping strategies table

\begin{tabular}{|l|l|l|l|l|l|}
\hline \multirow{2}{*}{$\begin{array}{l}\text { Female } \\
\mathrm{N}=442\end{array}$} & & $\begin{array}{l}\text { Cognitive } \\
\text { restructur- } \\
\text { ing }\end{array}$ & $\begin{array}{l}\text { Tension } \\
\text { reduction }\end{array}$ & $\begin{array}{l}\text { Problem } \\
\text { analysis }\end{array}$ & $\begin{array}{l}\text { Passive } \\
\text { coping }\end{array}$ \\
\cline { 2 - 6 } & Mean & 2,58 & 1,79 & 2,87 & 1,66 \\
\cline { 2 - 6 } & St.dev. & 0,50 & 0,59 & 0,43 & 0,63 \\
\hline \multirow{2}{*}{$\begin{array}{l}\text { Male } \\
\mathrm{N}=371\end{array}$} & Mean & 2,64 & 1,82 & 2,73 & 1,58 \\
\cline { 2 - 6 } & St.dev. & 0,49 & 0,68 & 0,48 & 0,68 \\
\hline
\end{tabular}

Source: Own resource

I also asked members of the measured sample questions about smoking and alcohol use. $79.3 \%$ of respondents (645 people) thought of themselves as non-smokers, 7.1\% (58 people) said they smoked occasionally (once or twice a month) and $13.5 \%$ (17 people) thought of themselves as regular smokers. Table 7 reveals a clear protective role of sport against smoking. 83. 3\% of competitive sportspeople do not smoke at all, while leisure-time ones show a lower percentage (79.8\% of them are non-smokers), and this trend continues among non-athletes: $71.1 \%$ of them are non-smokers. 
Table 7: Smoking habits among competitive and leisure-time sportspeople and non-athlete individuals

\begin{tabular}{|l|l|l|l|}
\hline & Non-smokers & $\begin{array}{l}\text { Smoked oc- } \\
\text { casionally }\end{array}$ & Regular smokers \\
\hline \multirow{2}{*}{$\begin{array}{l}\text { Competitive } \\
\text { sportspeople } \\
(\mathrm{N}=341)\end{array}$} & 284 & 25 & 32 \\
\cline { 2 - 4 } $\begin{array}{l}\text { Leisure-time } \\
\text { sportspeople } \\
\text { (N=292) }\end{array}$ & $83,3 \%$ & $7,3 \%$ & $9,4 \%$ \\
\cline { 2 - 4 } $\begin{array}{l}\text { Non-athlete } \\
\text { individuals } \\
\text { (N=180) }\end{array}$ & $79,8 \%$ & 16 & 43 \\
\hline Total (N) & $71,1 \%$ & $5,5 \%$ & $14,7 \%$ \\
\hline Total \% & 645 & 17 & 35 \\
\hline \multicolumn{5}{|c|}{ Source: Own resource } \\
\hline \multicolumn{5}{|l}{} \\
\cline { 2 - 4 } & $79,3 \%$ & 58 & $19,4 \%$ \\
\hline
\end{tabular}

According to my third hypothesis a difference could be assumed among smoking groups in terms of coping strategies. I analysed the hypothesis using the Kruskal-Wallis H test and the results showed that there was a significant difference in terms of tension reduction (Table 8).

Table 8: Coping strategies in terms of smoking habits

\begin{tabular}{|l|l|l|l|l|}
\hline & $\begin{array}{l}\text { Cognitive } \\
\text { restructuring }\end{array}$ & $\begin{array}{l}\text { Tension } \\
\text { reduction }\end{array}$ & $\begin{array}{l}\text { Problem } \\
\text { analysis }\end{array}$ & $\begin{array}{l}\text { Passive } \\
\text { coping }\end{array}$ \\
\hline $\begin{array}{l}\text { Kruskal- } \\
\text { Wallis H }\end{array}$ & 0,567 & 45,350 & 0,378 & 2,02 \\
\hline df & 2 & 2 & 2 & 2 \\
\hline Signifikancia & 0,753 & 0,000 & 0,828 & 0,365 \\
\hline
\end{tabular}

\section{Source: Own resource}

The differences are also borne out by the table below, which shows that mean values differ significantly only in terms of tension reduction. Smokers showed significantly higher means compared with non-smokers (Table 9).

Table 9: mean values and distribution of coping strategies in terms of smoking habits

\begin{tabular}{|l|l|l|l|l|l|}
\hline $\mathrm{N}$ & & $\begin{array}{l}\text { Cognitive } \\
\text { restructur- } \\
\text { ing }\end{array}$ & $\begin{array}{l}\text { Tension } \\
\text { reduction }\end{array}$ & $\begin{array}{l}\text { Problem } \\
\text { analysis }\end{array}$ & $\begin{array}{l}\text { Passive } \\
\text { coping }\end{array}$ \\
\hline $\begin{array}{l}\text { Non-smok- } \\
\text { ers (N=645) }\end{array}$ & Mean & 2,60 & 1,72 & 2,81 & 1,62 \\
\cline { 2 - 6 } & St.dev. & 0,46 & 0,58 & 0,44 & 0,65 \\
\hline $\begin{array}{l}\text { Smoked } \\
\text { occasionally } \\
(\mathrm{N}=58)\end{array}$ & Mean & 2,64 & 2,05 & 2,76 & 1,71 \\
\cline { 2 - 6 } & St.dev. & 0,59 & 0,68 & 0,53 & 0,64 \\
\hline $\begin{array}{l}\text { Regular } \\
\text { smokers } \\
(\mathrm{N}=110)\end{array}$ & Mean & 2,62 & 2,16 & 2,81 & 1,61 \\
\cline { 2 - 6 } & St.dev. & 0,66 & 0,76 & 0,52 & 0,70 \\
\hline
\end{tabular}

\section{Source: Own resource}

In terms of alcohol use $23 \%$ of respondents (187 people) said they never drank alcohol, $57.1 \%$ (464 people) drank only rarely (once a month), a further $17.8 \%$ (145 people) had alcohol once or twice a week with only $2.1 \%$ of respondents (17 people) saying that they drank alcohol on a daily basis (Table 10). As the table also shows, $82.4 \%$ of competitive sportspeople did not drink alcohol at all or only very rarely, while among leisure-time sportspeople this number was $78.5 \%$, with $78.3 \%$ for non-athlete individuals. Across the entire sample, $80 \%$ of them rarely or never drank alcohol.

Table 10: Alcohol use

\begin{tabular}{|c|c|c|c|c|}
\hline & Never & Rarely & Weekly & Daily basis \\
\hline \multirow{2}{*}{$\begin{array}{l}\text { Competitive sport- } \\
\text { speople }(\mathrm{N}=341)\end{array}$} & 79 & 202 & 54 & 6 \\
\hline & $23,2 \%$ & $59,2 \%$ & $15,8 \%$ & $1,7 \%$ \\
\hline \multirow{2}{*}{$\begin{array}{l}\text { Leisure-time sport- } \\
\text { speople }(\mathrm{N}=292)\end{array}$} & 65 & 164 & 59 & 4 \\
\hline & $22,2 \%$ & $56,2 \%$ & $20,2 \%$ & $1,4 \%$ \\
\hline \multirow{2}{*}{$\begin{array}{l}\text { Non-athlete indi- } \\
\text { viduals }(\mathrm{N}=180)\end{array}$} & 43 & 98 & 32 & 7 \\
\hline & $23,9 \%$ & $54,4 \%$ & $17,8 \%$ & $3,9 \%$ \\
\hline TOTAL $(\mathrm{N})$ & 187 & 464 & 145 & 17 \\
\hline TOTAL $\%$ & $23,0 \%$ & $57,1 \%$ & $17,8 \%$ & $2,1 \%$ \\
\hline
\end{tabular}

Source: Own resource

As my fourth hypothesis, I examined the differences between the groups that did drink alcohol in terms of coping strategies. I analysed my hypothesis using the Kruskal-Wallis $\mathrm{H}$ test and found significant differences in tension reduction, problem-analysis and passive coping (Table 11).

Table 11: Coping strategies in terms of alcohol use

\begin{tabular}{|l|l|l|l|l|}
\hline & $\begin{array}{l}\text { Cognitive } \\
\text { restructuring }\end{array}$ & $\begin{array}{l}\text { Tension } \\
\text { reduction }\end{array}$ & $\begin{array}{l}\text { Problem } \\
\text { analysis }\end{array}$ & $\begin{array}{l}\text { Passive } \\
\text { coping }\end{array}$ \\
\hline Kruskal-Wallis H & 1,691 & 10,548 & 11,465 & 12,521 \\
\hline df & 2 & 3 & 3 & 3 \\
\hline Signifikancia & 0,639 & 0,014 & 0,009 & 0,006 \\
\hline
\end{tabular}

Source: Own resource

As Table 12 also shows, alcohol use appears in three of the factors of coping strategies, and it was only in cognitive restructuring that mean values did not increase together with alcohol use (Table 12).

Table 12: coping strategies in terms of alcohol use

\begin{tabular}{|l|l|c|c|c|c|}
\hline $\mathrm{N}$ & & $\begin{array}{c}\text { Cognitive } \\
\text { restructur- } \\
\text { ing }\end{array}$ & $\begin{array}{c}\text { Tension } \\
\text { reduction }\end{array}$ & $\begin{array}{c}\text { Problem } \\
\text { analysis }\end{array}$ & $\begin{array}{c}\text { Passive } \\
\text { coping }\end{array}$ \\
\hline $\begin{array}{l}\text { Never } \\
(\mathrm{N}=187)\end{array}$ & Mean & 2,57 & 1,75 & 2,72 & 1,71 \\
\cline { 2 - 6 } St.dev. & 0,51 & 0,63 & 0,44 & 0,70 \\
\hline Rarely & Mean & 2,62 & 1,78 & 2,84 & 1,61 \\
\hline$(\mathrm{N}=464)$ & St.dev. & 0,47 & 0,61 & 0,44 & 0,63 \\
\hline Weekly & Mean & 2,63 & 1,88 & 2,82 & 1,50 \\
\hline$(\mathrm{N}=145)$ & St.dev. & 0,55 & 0,63 & 0,48 & 0,62 \\
\hline Daily basis & Mean & 2,49 & 2,33 & 2,73 & 1,94 \\
\hline$(\mathrm{N}=17)$ & St.dev. & 0,60 & 0,96 & 0,71 & 0,77 \\
\hline
\end{tabular}

Source: Own resource 


\section{DISCUSSION}

The results of my examination confirmed my assumption that there were differences between competitive and leisure-time sportspeople on the one hand and non-athlete individuals on the other in terms of intrapersonal coping strategies. In difficult life situations competitive and leisuretime sportspeople prefer cognitive restructuring of all the measured coping strategies.

My assumption that there were differences between the genders, too, in terms of coping strategies was also confirmed. The female members of the sample showed a significant difference compared with the male members in terms of passive coping and problem analysis.

In this study I also found an answer to the question how smoking and alcohol use appeared as a negative way of coping in competitive and leisure-time sportspeople and non-athlete individuals. The results led us to conclude that smoking has a tension reducing function in the coping process. Its protective role against smoking in sport also appeared, which contradicts previous research (Peretti-Watel, 2002).

In terms of sporting habits and the frequency of alcohol consumption I found that competitive and leisure-time sportspeople and non-athlete individuals consume alcohol with similar frequency; almost the highest percentage belongs to competitive sportspeople who never or just rarely drink alcohol, a finding which, again, runs counter to previous studies (Grossbard et al., 2007; Veliz et al., 2015).

Frequent alcohol consumption has a tension reducing role in the coping process and is characterised by passive coping. However, moderate alcohol use is accompanied by a significant increase in problem analysing ability.

People use different ways of coping in different life situations which are often situation-specific and do not lend themselves to unambiguous generalisation. An unambiguous assessment of coping strategies is made difficult by the fact that in different life situations an individual tends to use the same coping strategy from time to time in the coping process (Schwarzer and Schwarzer, 1996). This it becomes understandable that while a particular coping strategy (e.g. praying, eating or drinking, and smoking) appear totally adaptive with reference to a given period, in a later period the used strategies are not necessarily effective.

\section{CONCLUSION}

In my research, which I conducted among competitive and leisure-time sportspeople as well as non-athlete individuals, I examined what kind of coping strategies are used in difficult situations. As a cumulative result we can conclude that competitive and leisure-time sportspeople showed significantly higher values in their use of cognitive restructuring compared with non-athlete individuals. Cross-gender examination revealed that females possess significantly more passive ways of coping than males. I also found significant differences in terms of problem analysis.

In terms of psychoactive substance use I examined smoking habits and alcohol use. In terms of smoking the protective role of sport occurs. In the three examined groups the number of smokers decreased together with an increase in the intensity of sport. In the case of smokers tension reduction increases significantly, that is, smoking becomes realised as a negative coping strategy.

In the case of alcohol use I found significantly higher values for the coping strategies of tension reduction, problem analysis, and passive coping.

Obviously, sportspeople's psychoactive substance use can also be affected by factors other than sporting habits, which are, on the one hand, sport specific (nature of sport: individual versus team sport, atmosphere in the sports organisation, frequency and level of competing, etc.) and diverse psychosocial factors (stress, anxiety, depression, financial and social situation, etc.), and on the other hand, can also play a role in the use of coping strategies. The complex examination of these factors can contribute to a better understanding of the examined topic and we can arrive at a more precise answer whether sport does play a substantial role in influencing coping mechanisms and use of psychoactive substances.

The publication is supported by the EFOP-3.6.2-16-201700003 project. The project is co-financed by the European Union under the European Social Fund.

\section{REFERENCES}

Crawford G., Gosling V. (2009): More than a game: Sportsthemed video games \& player narratives. Sociology of Sport Journal, 26(1), 50-66

DEAC (2019): http://www.deac.hu/szakosztalyok/esport

ENet (2017): Közel 200.000. hazai e-sport játékos, az esport számokban https://enet.hu/hirek/kozel-200-000-hazai-e-sportjatekos-az-e-sportrol-szamokban/

ENet (2018a): E-sport: kevesek szórakozásából feltörekvő iparág, https://enet.hu/hirek/e-sport-kevesek-szorakozasabol-feltorekvo-iparag/

ENet (2018b): Magyarország 3,7 millió játékos hazája, http:// enet.hu/hirek/magyarorszag-37-millio-jatekos-hazaja/

ENet (2019a): A Magyar videojáték piac több mint felét az esport adja, https://enet.hu/hirek/a-magyar-videojatek-piac-tobbmint-felet-az-e-sport-adja/

ENet (2019b): Egyre többet költünk viedojátékra https://enet. hu/hirek/egyre-tobbet-koltunk-videojatekra/

\section{European Sport Charter (1997): Article 2}

Flancher B. (2019): Jöhet a magyar esportkánaán? https://index. hu/tech/godmode/2019/05/25/esport-mneb-hunesz-verseny-v4future-sports-magyar/ 2019.09.13. 
HUNESZ (2018): MNEB Versenkyiírás, https://hunesz.hu/ documents/Magyar-Nemzeti-E-sport-Bajnoksag-versenykiiras2018-2019-ideny_2.pdf 2019.08.27.

Impey S. (2018): Most-watched esports events record $190.1 \mathrm{~m}$ streaming hours. http://www.sportspromedia.com/news/esports-tournaments-record-live-streaming-hours 2019.07.25.

Leet (2019): A magyar esport történelem legnagyobb sikerei https://leet.hu/2019/07/24/osszegyujtottuk-nektek-hazank-esporttortenelmenek-legkiemelkedobb-alakjait-es-eredmenyeiket/

Needleman SE. (2015): “Twitch's Viewers Reach 100 Million a Month", The Wall Street Journal, https://www.wsj. com/articles/facebook-embraces-esports-in-its-video-strategyshift1495099801 2019.10.01.

Needleman SE., Seetharaman D. (2017): "Facebook Embraces Esports in Its Video Strategy Shift", The Wall Street Journal, https://www.wsj.com/articles/facebook-embracesesports-in-itsvideo-strategy-shift-1495099801 2019.08.14.

Newzoo (2017): White Paper: An Overview of Esports in Europe

Noyes D. (2019): The Top 20 Valuable Facebook Statistics, https://zephoria.com/top-15-valuable-facebook-statistics/ 2019.10.01.

Olsen AH. (2015): The evolution of eSports: an analysis of its origin and a look at its prospective future growth as enhanced by Information Technol-ogy Management tools. arXiv preprint arXiv:1509.08795.

Pannekeet, J. (2019): More People Are Streaming on Twitch, But YouTube Is the Platform of Choice for Mobile-Game Streamers https://newzoo.com/insights/articles/more-peopleare-streaming-on-twitch-but-youtube-is-the-platform-of-choicefor-mobile-game-streamers/ 2019.09.29.

PwC (2018): Az e-sport nem játék, Üzleti elemzés Magyarország és a V4-ek e-sport-piacáról, https://www.pwc.com/hu/hu/ kiadvanyok/assets/pdf/esport.pdf 2019.08.23.

Szabella, O. (2018): Korunk virágzó biznisze? Az e-sport iparág be-mutatása, Információs Társadalom, XVIII(1) pp. 66-92.

Zsédely, P. (2017): Mennyit ér a szponzoráció az eSportban? A Nielsen felméri! http://sportsmarketing.hu/2017/08/24/mennyiter-a-szponzoracio-az-esportban-a-nielsen-felmeri/ 2019.10.02. 